SCHOLARS: Journal of Arts \& Humanities

[Peer-Reviewed, Open Access, Indexed in NepJOL]

Print ISSN: 2773-7829; e-ISSN: 2773-7837

Volume 1, August 2019, pp. 91-104

DOI: https://doi.org/10.3126/sjah.v1i0.34451

\title{
The Death Rite in New Republic Nepal: Should It Be Shortened?
}

\author{
Shiva Ram Rijal, PhD \\ Central Department of English \\ Tribhuvan University, Kirtipur, Kathmandu, Nepal
}

\begin{abstract}
I introduce an on-going debate on whether and how should rituals be tamed in the contemporary Hindu society of Nepal. In this paper, I point out intellectuals who espouse secular thoughts hesitate to talk about rituals in public. On the other hand, there are also many who believe these rituals as their forte. Out of this trajectory of thoughts, I develop an argument that there is a lack of force that could promote interpretative understanding of rituals in Nepal. Based on a line of thoughts propounded by Roy A. Rappaport, Catherine Bell, and Hannah Arendt, I maintain that rituals need to be taken as part and parcel of ritual-making zeal of humankind. With a brief introduction about the historicity of ritualization in Nepal, I highlight the adoptable characteristics of rituals in the Kathmandu Valley and the role the people of the valley have started to point out a possibility of bringing reformation in death rituals.
\end{abstract}

Keywords: Vedic, ritualisation, sanskritisation, communitas, redressive mechanism, intervention

\section{Introduction}

Nepal has gone through challenging times jammed with issues of the past, present and future. The age-old monarchical system came to an end in 2008. The implementation of new constitution and establishment of federal restructuration of the state have remained the strongest driving political forces. The ongoing political transformation has also triggered some debates about rituals in practice since ancient times. Rituals that the Hindu societies live by have become the subjects of concern for political parties from extreme left to the ultra-right wing in recent years. Similarly, SCHOLARS: Journal of Arts \& Humanities 
The Death Rite in New Republic Nepal: Should It Be Shortened? 92

positive changes taking place in rituals have also drawn media attention. For example, when women from Tanahu district, the western part of Nepal, carried out funeral procession of a woman who died in a local old age home, it drew the attention of the press. National dailies took the funeral procession as the metaphor of Nepal that is changing in a positive way (Kantipur, 09 Nov. 2014).

Not only death rites but other animal sacrifice rites are also under social scrutiny in the federal system. The famous Gadhimai festival that is held in every five years in Gadhimai temple of Bara District, southern part of Nepal, drew the attention of animal rights activists worldwide in November 2019. Despite a series of protests, the animal sacrifice took place in a huge scale. Bizarre pictures of the sacrifice - the blood soaked ground and animals lying with severed trunks - were posted on social media and came out in media reporting of the event. In the meantime, the Nepal government has officially announced plans to support certain economic funds to promote widow marriage and also inter-caste marriage, thereby, reversing at least on a limited scale the ritual practices that have roots in the caste-discriminatory past. However, news about sufferings and tragic ends of inter-caste married couples fill the media coverage such as TV screens in Nepal.

Conflicting views dominate the discourse on rituals in Nepal. On the one hand, leaders espousing the left and democratic political views, as if it were for the first time, have spoken openly about the exigency of making death mourning rituals shorter and smarter. On the other hand, conservative political parties are trying their best to reinstate them qua Nepal as a Hindu state. The idea is, they believe, as the rituals of the Hindus as prescribed in the Vedas are the most sacred things beyond the grasp of mortals, and they can be saved only by attaching them to the hegemony of Hinduism as a dominant view as well as a system of discipline.

The guru of many Nepali communist leaders, Mohan Bikram Singh, who lived underground for several decades, believes that reformative movements within religion seen as "common experience in many religious countries including India” are not going to happen soon in Nepal (34). But as a staunch communist, he repeats the communist jingle that the day will come when "progressive forces will take over the orthodoxy” (37). Former Education Minister Modanath Prashreet who had been a politburo member of the former Nepal Communist Party, a famous poet and now an opponent of proselytization in Nepal argues that it is high time to make the thirteenday-long death rituals practiced among the Nepali Hindus shorter and simpler (45) in order to address the aspirations of people. Narahari Acharya, a former minister and the member of the Central Committee of the Nepali Congress and a literary critic, points out that instead of the modern state getting involved into the act of reforming rituals, it is people within the communities who should take up such a cudgel (46). He 
The Death Rite in New Republic Nepal: Should It Be Shortened? 93

further proposes that the thirteen-day-long death ritual should be shortened to five days (51). Khagendra Sangraula, the leading Marxist writer, points out the urgent need of debunking certain episode from the Hindu death rituals, mainly the recitation of Garud Purana (57). Garud Purana tells harrowing stories that happen to the departed soul in the inferno. This book is seen as the most reactionary interpretation and rituals by harping on the tenets of the Hindu perception of hell, heaven, and salvation. Ghanashyam Sharma Paudyal, a leftist academic, blames the Brahmins for creating mess in the society by capturing gods in their hold. He throws a rhetorical card that since Brahmins themselves "do not live or act out the prescribed ritualistic life, then why should common people practise rituals in the same form as they suggest?” (79). Another leftist and Sanskrit scholar Bishnu Dahal opines that the Hindu rituals associated with life force rather than the ones associated with death should be promoted (123). An orthodox Sanskrit scholar Ram Chandra Gautam points out that rituals cannot be treated freely as he claims: "Even the principles and rituals propounded by the Puranas are not given authenticity until they are justified on the principles prescribed in the Vedic texts” (132). Foreign Minister and member of the Politburo of Nepal Communist Party Pradip Gyanwali critiques his leftist friends for holding a very limited understanding about the paramparik arts and cultures of the country. He says that traditional plays, festivals, and rituals are much more than mere mediums for social and political transformations (146). Aahuti, himself a Dalit and a staunch leftist ideologue and fiction writer, critiques the domination of rituals in the Nepali Hindu society on the ground of human right as he argues: "It is the parents' rights, not that of any priest, to name the children. And it is the very individual who after reaching a mature age should have right to choose his or her name" (171). As a former Maoist leader, Aahuti points out that people in power have deliberately promoted rituals favourable for them. In this process, they have made other people's life miserable. He argues that the very centre of power must realise this guilt (159).

The above survey reveals a point that scholars and ideologues agree that rituals associated with death rites have become burden to the Hindus in Nepal though Nepal as a modern nation state hesitates to intervene into the domain of rituals of the Hindus. Political ideologues and intellectuals have sympathy for the victims of rituals. But, they also do not have any strategy to enter the domain of rituals and turn the tide of suffering. On the contrary, caste-discrimination is still rampant, and rituals have remained the least intervened areas. Now the questions come: Who will bell the cat? Can rituals be made liberal simply by talking about them or simply by critiquing Brahmins? How are communities to decide about reforming rituals? Who are going to motivate or guide them? 
The Death Rite in New Republic Nepal: Should It Be Shortened? 94

\section{Of Core Values and Beyond}

Addressing the questions raised above requires the one to realise the limitation of existing understanding about rituals. Victor Turner points out that the rituals are part of redressive mechanism that people perform to address personal and social crises in their life: "Redressive action is often ritualised, and may be undertaken in the name of law or religion" (8). Ritual performances become synonymous with key moments in life of the members of the community. Such occasions bring persons and symbols crucial to know who they are, what faiths they need to embody and so on: "Rituals bring core cultural values, ideology, knowledge and dramatic style to bear on real social relationships, problems and difficulties, often at key moments of transition or intensification" (Schieffelin18). Such ritual occasions also create moments when the intangible knowledge and wisdom crucial to run life and community as well as the very rituals are handed over to the new generation. Rituals, in the words of Jeffrey C. Alexander, become moments of "cultural communications" when ". . . mutual belief in the descriptive and prescriptive validity of communication's symbolic contents" takes place and people "accept the authenticity of one another's intentions" (29). Such moments are necessary to renew the bond between and among the members of the community.

Anthropologists argue that rituals are sometimes deliberately given extrahuman attributes by their practitioners. Texts both in written and oral forms support and disseminate such extra human attributes of rituals. As a matter of faith, people love to take rituals as divine forms of expression. Claus Ambos points out that people take ritual and divinity in "a fairly homogeneous system" (41). Real ritual symbols, space, and time become inseparable from the divine power, space, and time. Clifford Geertz points out this very fusion of real and imagined world in his very famous definition of rituals in this way: "In ritual, the world as lived and the world as imagined, fused under the agency of a single set of symbolic forms, turns out to be the same world" (112).

Rituals have also been interpreted as part and parcel of power politics. As media of hegemonising truths, they are often projected as 'unquestionable' entity. Any question raised against rituals is taken as violation of culture, parampara and political authority. So much so, going against rituals becomes psychologically a haunting experience. Rituals are often projected as subjects beyond the control of very performers and audiences: "The unquestionable-ness that constitutes the essence of the sacred is a product... of the acceptance intrinsic to the performance of invariant orders encoded by other than the performers, and a product of the certainty intrinsic to that which is represented as without alternative" (343). In this process, the very culture of interpreting rituals, the way they have been mystified and disseminated and so on become as much 
The Death Rite in New Republic Nepal: Should It Be Shortened? 95

powerful as rituals themselves. This, further, creates a hermeneutically sealed zone from where even the priests and performers of rituals cannot liberate. In such a psychosocial trap, rituals become much more than the practices conducted in the name of connection between self, community, and the universe. Ironically, they become specific and unquestionable practices. Though human-made constructs, rituals are denied to expose the secret of their own genesis. They become 'beginningless' and 'authoritative' to hegemonise certain religious perspective for numbers of members of the community. Evoking similar features of the Hindu rituals, Stietencron writes: "In the search for the "essentials" of Hinduism ... the recognition of the Vedas as beginningless and authoritative holy scriptures... seemed to dominate in all walks of life. Yet none of these so-called fundamentals of Hinduism applies to all religions in Hinduism" (235). Such an act of gluing rituals to the Vedic times has frozen the very rituals there and then. But the fact of the matter is that rituals have different dynamism. Scholars have pointed that rituals of the post-Vedic times, mainly those based on the Upanishads and the Bhakti traditions are more progressive.

The Nepali Hindu priests and kings used certain archaic rituals to define lifestyle the people in the past. Importantly, marriage was first and foremost defined ritually as well as legally. Anyone going against the ritual 'norm', marrying widow or somebody else's wife became a subject of punishment ritually and socially, and even legally according to the MulukiAin, the legal code promulgated in 1854 by theautocratic Rana regime. This form of downgrading people was further given permanency as such couples and their progenies were denied any access to read the Shastra and perform the very rituals: "Thus Dalits, deprived of high-caste priestly services and denied the opportunity to go through Sanskritically legitimated initiation rituals, are condemned for being "without dharma" and are correspondingly viewed, traditionally, as being non-persons or lesser persons” (Gellner 169). This psychosocial reality generated through fusion of rituals and political power provided a sacred status to one particular caste at the cost of humiliating other communities. The culture of developing rituals to establish and interpret human body as part and parcel of the universe, and "the seat of cosmic planes" (17) did pave the way for rituals that regarded such body as "social body" (Michaels 13), a site of perennial social punishment.

The ritual generated socio-cultural realities demand upon the liberal thinkers to develop critical perspectives about the very world of rituals. The fact that rituals themselves are the subjects of human creation that provides a ground for its scrutiny. In this case, Catherine Bell claims: "Definitions of ritual must go on to suggest, explicitly or implicitly, the nature and relation of nonritual activity and various degrees of nearly-but-not-quite-ritual behaviour" (69). The call of Bell is deconstructive that asks one to trace down the very political and poetic path that 
The Death Rite in New Republic Nepal: Should It Be Shortened? 96

rituals have travelled all the way to the people. Rituals are part and parcel of politics and humanities. As attempts made to solve riddles of life in the universe, they need to be taken as open and free texts and cultural practices. Rituals were an eye-opener for people to delve further into fathomless life and the universe. Evoking this very nature of rituals, Alex Michael argues that the established way of taking rituals as "perfect" and "god made" should be seen as "the imperfect realisation of the idea of perfection" (131). Moreover, the very Vedas which most of the pundits often refer to establish authenticity of their rituals speak for multiple ways of conducting rituals and so on: "Shastras composed according to the Vedic parampara mention about 10, 16, 25, 40 and 48 different ways of conducting rituals" (Acharya 47) though some specific ways of conducting rituals were given deliberate emphasis in particular phase of sociopolitical history of a particular part of India and Nepal. There are alternatives in the rituals, too. This side of the Hindu rituals has not been much discussed in the Nepali societies.

\section{Sanskritization vs. Ever-present State of Rituals}

Ritual-based current Nepali psychosocial realities have a direct connection with the process of Sanskritization of the societies in the past. This connection also reveals the roles which leaders and local custodians can play in either loosing or taming the rituals. State heads are often found imposing the rituals from above. On the other hand, the local custodians keep on performing tactics to tame the rituals. Sanskritisation is defined as "the processes by which a 'low' caste or tribe or other group takes over the customs, ritual, beliefs, ideology and style of life of a high and, in particular, a 'twice-born' ( $d w i j a)$ caste” (Srinivas 88). It was historically a dominant medium of hegemonising rituals, especially in the areas where the political and intellectual forces associated with the sphere of knowledge in the Sanskrit language became dominant.

The priestly caste monopolised the use of Sanskirt and rituals. Political, social, and economic changes of latter times came to play a major role in establishing rituals in the Hindu societies. Scholars like Sheldon Pollock, Romila Thapar, and M.N. Srinivas have written extensively about the changes and transformations that the culture did go through in the latter times in India, for that matter in Nepal, too: "Ritualisation (the restriction of Sanskrit to liturgical and related scholastic practices) and monopolisation ...gave way to a new sociology and politicization of the language just around the time that western Asian and central Asian peoples were entering into the ambit of Sanskrit culture” (12), opines Sheldon Pollock. In addition, the political and military power force that the Sanskrit-language speakers came from or played an important role in creating 'inferior' class. As a result, "those speaking a non-Indo- 
The Death Rite in New Republic Nepal: Should It Be Shortened? 97

Aryan language were frequently given a low rank and described as mleccha” (317), argues RomilaThapar. This form of social transformation was in favour of people in the upper echelon of communities brought "opportunities for seizing political power were more likely to be available to the leaders of the dominant castes, and even tribes, than to others" (Srinivas 74).

This form of political and military force and its expansion paved the way for newer socio-political cultures, and this motivated priests and scholars to invent newer rituals: "Puranic rituals often replaced Vedic rituals", and the newer rituals were "devoted to the more worldly goals of the path of rebirth, and the end of the line is not absorption into Brahman but an eternity in the heaven of the sectarian god to whom the Purana is devoted” (n.p.), contends Wendy Doniger. Scholars have further pointed out that rituals of the Vedic period did go through significant transformations and became something else in the period that followed. In this regard, Christof Zotter notes: "In the post-Vedic period, the principles of accretion introduced so far - the transfer or creation of new core elements, the framing by a fire ritual, and the adoption of puja-based standards- were used not only to modify existing ritual but also to construct a completely new samskara" (33). Naturally, the Hindu rituals also went through transformation during the period when Muslim invasion took at a bigger scale in India: "For the Hindus, the most serious drawback was the loss of patronage and influence in public and cultural life. This weakness was bitterly felt" (Stietencron 287).

But the process of Sanskritisation of the society through initiating and controlling rituals did not take place in a monolithic way. One cannot take for granted that the Indo-Sanskrit scholastic Brahmins were the givers, and the people at different echelon of societies were sans interpretative power of rituals; thus they received them helplessly. The history of Newar culture of the Kathmandu Valley has revealed that several communities have received and appropriated the Vedic rituals: “...each rite was constructed to work on multiple levels, to impart meanings and secure blessings differentially for those all along Buddhism's "gradual path”, from beginners to advanced tantric practitioners, from little children to elder adepts” (Lewis 185). The power of the Newar culture of Kathmandu has been appreciated in terms of its capabilities of absorbing and appropriating the Sanskrit rituals. Evoking this very power of the Newar performance culture, Alexander von Rospatt opines, “....the Buddhist versions of the different samskaras current among the Newars owe, to differing degrees, to adaptation of practice that was initially developed with regard to deities” (254). Furthermore, the Indo-scholastic texts and philosophies were not received tabula rasa in the valley. Farmers have played an important role in maintaining the heritage of age-old performance cultures of the valley. Evoking this 
The Death Rite in New Republic Nepal: Should It Be Shortened? 98

side of the Newar performance cultures, playwright Abhi Subedi asserts: "To understand the unique performance culture of the Nepal Mandala therefore it is very important to see how the farmers combined agriculture with sophisticated architecture and created urban spaces... made performances on a calendrical or seasonal basis" (13). The researchers have further pointed out that ritual handbooks in the Newar communities have remained diverse. Such texts have been deliberately modified to meet the necessity of people: "Such a text is always at the disposition of the ritual practice- despite its fixation on liturgical prescriptions. It is discussed and competed" (Gutschow and Michaels 172). Therefore, that the Brahmins or Sanskrit speaking scholars alone could or can create or play with rituals is not valid. Every place as a matter of exigency has a ritual interpreter and he or she plays important role in the modus operandi of rituals. For instance, Alex Michaels opines, “...by complex processes of ritual transfer and invention, and of merging and supplementing ritual and textual elements, various ritual specialists, not only Brahmins, create new and specific form of Hindu initiation that deserves to be treated - in Don Handelman's words - 'in its own right'” (149). Mobility and transformations in rituals have remained a continuum, and this is should not be taken as the case of the Kathmandu valley alone.

Such transformations make one to accept a fact that rituals are not apolitical sites. They cannot be studied sans their experts and their ideology. The ritual experts, priests, sacrifiers or yajaman and so on become actors as well as mediums for installing changes in ritual performances. Much depends on their notion about rituals. Evoking the dynamic side of rituals, Catherine Bells claims that "ritualisation is a strategy for the construction of a limited and limiting power relationship. This is not a relationship in which one social group has absolute control over another, but one that simultaneously involves both consent and resistance, misunderstanding and appropriation” (27). Ritual dynamism reveals a fact that the rituals brought in or practiced by conquerors too have gone through the process of transformation after they get new performers of new places and times. The ritualisation process passes through the repertoire of already existing rituals of the land. Gutschow and Michaels point out that the Newars of the Kathmandu valley have appropriated the several Sanskrit dominated ritual textures: "Mantras have been deliberately rearranged, differently combined, extended, reduced, or applied in different mythological or ritual contexts" (166). The Newars though lost the war and their kingdom to the Hindus of the Hilly region, they have maintained the power of appropriating the Brahmin and Sanskrit dominated rituals. This evokes the creative role that human resources can play in taming rituals. Since human actors play an important role in performing and modifying rituals, rituals can be made and remade: "Relatively little attention has 
The Death Rite in New Republic Nepal: Should It Be Shortened? 99

been paid to how the presence of specialists affects ritual practices. Their presence or absence is usually taken simply as an index to the importance of ritual or the stratification of society” (Bell 130). Each social group has distinct ritual practices, this establishes an important critical premise that there exist certain people who hold some power to interpret rituals, and to whom people come for consultation. This everyday necessity challenges the hegemony of any single module of ritual practice. Gutschow and Michaels after their years long research on birth, death and growing up rituals of the Newar Hindus of the Kathmandu valley reach to the conclusion that: “...rituals and their texts have to be seen in a new light, because they offer far more freedom than has generally been accepted" as not only handbooks and priests performers but "also the sacrificer or 'Yajaman"” provide flexibility to the rituals, making one believe that "rituals as well as ritual texts much less formal than they might at first appear" (2). Liberal intellectuals need to provide dynamism to this 'less formal' feature of rituals.

Rituals have histories as well as local stories. They should also be seen in terms of their ever-present state. Rituals are acts of renewing seasons, therefore, of time and self, too. They remind us of the circularity of time and life experience. Rituals also tell us that they have always been in the process of transformation. Coming or passing of rituals from one era and place to another reveals a fact that they absorb changes. Rituals can disappear; they can acquire bigger paraphernalia. Rituals can be hegemonic and also bear inter-textual textures and so on. Moreover, one should understand rituals in their ever-present state, not as mere things of the pasts and residues of the older civilizations but as continuum. They should be seen in terms of ritual making zeal of people. No matter how secular one may claim that the societies in the subcontinent to be, dharmic or religious gurus of the present times have been found deliberately creating rituals of new order to draw the attention of the mass. Profit in their card, they have been using several strategies to make people believe in the rituals they have created and spread. They too deliberately try to convince that the rituals they perform are god given and come from the very source of beginning. Rituals are going through changes right here and now in front of free media, too. Proselytisation may have a connection with the suffering of downtrodden 'low' castes and also with freedom of individuals in Nepal, but still it cannot be separated from Nepal's economic dependence upon donor nations. Economically and militarily powerful class takes its religion and rituals wherever it goes or stays. Similarly, the popularity of Indian dharmic gurus cannot be separated from the direct political and cultural influence that India has upon Nepal. The home-brewed power elites have their own cult of gurus, who play an important role in promoting rituals they live by. Brahmins still hold the domination over ritual texts and the culture of 
The Death Rite in New Republic Nepal: Should It Be Shortened? 100

interpretation. Therefore, now a question arises why should only few have the power of playing with rituals?

Therefore, rituals need to be seen in terms of the most ancient human instinct of addressing human existence in this universe. Egalitarian, liberal, and poetic rituals should be used as source of creativities whereas rituals, which demand repairing and renovation should be revisited. This form of art, skills, and wisdom should be seen as inherent human instinct. Roy A. Rappaport argues,

The conditions that make it possible for some men to promulgate conventions by directives to which other men must conform seem to have developed relatively recently, probably not antedating by much, if at all, the appearance of plant and animal cultivation 10,000 years or so ago. Ritual, on the other hand, does not require superordinate human authorities to establish conventions and must have antedated procedures that do. (132)

Texts, priests, and parampara of ritual performances become secondary to the realisation of being in this universe amid plants and planets, animals and humans, land and sky and so on. Rituals, therefore, are as naked as human body. Rituals that try to hegemonise certain political propaganda, therefore, should be counter-balanced. There is always a need to develop arts and wisdoms to use rituals to repair the 'wrong' in rituals. One should keep in mind that rituals are 'artifice', to borrow a critical term from Hannah Arendt, constructed to make life easier and meaningful. One should neither forget this ancient and primeval instinct of creating rituals nor should one be indifferent to the rituals which need to be repaired to make peoples' live easier and happier: "The earth is the very quintessence of the human condition, and earthly nature, for all we know, may be unique in the universe in providing human beings with a habitat in which they can move and breathe without effort and without artifice” (2). Rituals should be seen in terms of the adventure that human beings have taken in making 'artifice' to make their life easier and joyful.

Thus, the performers of rituals do not only perform rituals; they also perform the historicity of performing rituals. In doing so, they also happen to perform change and continuity within the parampara of performing rituals. They perform what they know and also do not know. Such liminal state of handling rituals also provides opportunity to bring reformation within. People in general may believe that rituals are fixed, prescribed, and serious, but a deeper look at them reveals, "There is still room for the rearrangement of elements, and even for discarding some elements and introducing others, but invention is limited and the sanction of previous performance is maintained" (Rappaport 32). Like architectural sites, rituals too are subject of repairing, renovation, and innovation. Rituals provide us clues to realise the poetics 
The Death Rite in New Republic Nepal: Should It Be Shortened? 101

and politics behind their performativity. They provide further clues to move ahead. Rituals, one can here further say, are the sites of revisit and a subject of taming. This demands us to see them from multiple perspectives. Often regarding rituals, as part of human civilisation sans proper check and balance may not help one neither will it be wise to debunk them bluntly. Rituals, one can further say, are sites of active participation, negotiations, assertion of rights, and identity. Power elites have always promoted the rituals they love to live by. So have the priests. Thus, it depends on the power of interpreters of liberal minds. One speaking for egalitarian society and values should enter this world with confidence and rights, with purpose and zeal, not with humiliation and guilt.

\section{Individual Does His or Her Ways}

In the context of the on-going debate among pundits and the ideologues regarding the question whether death rites should be shortened, some individuals have already started to speak about the necessity of shortening death ritual in Kathmandu. The tragic demise of a renowned doctor Upendra Devkota, neurosurgeon and founder of the first neurological trauma unit in Kathmandu Nepal, on 18 June 2018, due to bile duct cancer, and the death rituals conducted in his name as per his last wish can be taken here as a case in point. Social media and people kept on following the news about his health and treatment almost on a daily basis. National dailies provided space for the news about his last days continuously for several days. For example, the moment he spent at his home, a non-descript village at Gorkha, where he was born and the water that he drank from the local tap according to his last wish, was shown by visual media, and it was published on the front pages of newspapers. Deshsanchar, an online portal, ran a series of articles based on interviews with Devkota and kept on reporting not only the news about Devkota's health, but also about his past life, and the work he would have loved to do in the future. He lived with a sense of freedom and dedication to his profession.

A classmate of Nepali leftist leader such as Baburam Bhattarai, former Prime Minister and others, Devkota quietly focussed on his own studies and career. Father of three daughters, he asked his wife and family members to conduct his death rites for seven days only and cremate his body at a recently opened electric crematorium. Respecting his wishes, his three daughters and wife conducted the rituals according to his wish. The visual and the news of Devkota's three daughters, accompanied by their relatives, carrying his body from the Pashupati river bank to the crematorium became viral in on social media. Daughters conducting death rites of their father - though a rare practice in Nepal, a Hindu dominated country - this particular case has drawn the attention of media and public to a great extent. Significantly, Devkota's last wish and 
The Death Rite in New Republic Nepal: Should It Be Shortened? 102

the rituals conducted accordingly have also triggered a debate among the conservative Brahmin intellectuals, the die-heart supporters of the thirteen-day-long death rituals. The Sanatan Bidwat Parishad, Nepal, with the aim of maintaining the death rituals in their original forms and lengths has come up with a book that contains articles, which vehemently support the rituals to be maintained in their usual forms and contents. Amodhbardhan Kaundinnyayan, a staunch supporter of the status quo, prescribes and reiterates the names of the books and publication details to be consulted and followed to maintain the existing order. He argues that the Vedas should be taken as the origins of all rituals. He praises Jayasthiti Malla for instilling the rituals in their pure forms and the role he provided to the priests. This looks as if the Sanatan Bidwat Parishad itself has taken the seven-days-long rituals conducted on Devkota's last wish as a major event that needed to be countered with a force they live by.

\section{Conclusion}

I would like to end this article with the remark that rituals especially the death rites cannot be seen as strict and closed texts as the staunch Hindu priests have defined, nor can it be seen in too open and liberal ways as the liberal and revolutionary ideologues have been advocating in new Republican Nepal. Political ideologues and intellectuals in Nepal live with the memory of political movement that brought an end to the Shah dynasty. They seem to favour changes and reformation and speak the language of the liberal and egalitarian society. But reformation in the domain of rituals may not be the same as the political and social changes brought in by the political ideologues and leaders in the post-2006 political context of Nepal. Nor can rituals be taken as stable and rigid as the conservatives often love to define them. Death rituals though conducted among family members and relatives, no doubt with the help of family priest, can also be taken as sites where individuals can enter the way Upendra Devkota was advocating. Such intervention can happen quietly as a matter of personal freedom.

\section{Works Cited}

Aahuti. “Janmadekhi Mrityu sammaka Samskar: Kehi Tippani.” Samskar (Rituals), compiled by Khagendra Sangraula, Vivek Srijanshil Prakashan, 2014 (2071 Bikram Samvat), 157- 175.

Acharya, Narahari. “Sanatan Samskarra Tinako Sarilikaran.” Samskar (Rituals), compiled by Khagendra Sangraula, Vivek Srijanshil Prakashan, 2014, 38-45.

Alexander, J.C. "Cultural Pragmatics: Social Performances between Ritual and Strategy.” Social Performance, edited by Jeffrey Alexander, Bernhard Giesen and Jason L. Mast, Cambridge UP, 2006, 29-90. 
The Death Rite in New Republic Nepal: Should It Be Shortened? 103

Ambos, Claus. "Types of Ritual Failure and Mistakes in Ritual in Cuneiform Sources.” When Rituals Go Wrong: Mistakes, Failure, and the Dynamics of Ritual, edited by Ute Husken, Brill, 2007, 25- 48.

Arendt, Hannah. The Human Condition. U of CP, 1988.

Bell, Catherine. Ritual Theory, Ritual Practice. OUP, 2009.

Dahal, Bishnu. "Sanskritik Navajagaran Aandolonko Aalokama Samskar Bidhi." Samskar (Rituals), compiled by Khagendra Sangraula, Vivek Srijanshil Prakashan, 2014, 118-130.

Doniger, Wendy. The Hindus: An Alternative History. The Penguin Press, 2009.

Gautam, Ram Chandra. "Garbhadhan dekhi Mrityu sammakd Samskar- Shastirya EbamVaigyanik Drishtikon.” Samskar (Rituals), compiled by Khagendra Sangraula, Vivek Srijanshil Prakashan, 2014, 131-145.

Geertz, Clifford. Interpretation of Culture. Basic Books, 1973.

Gellner, David N. "Initiation as a Site of Cultural Conflict". Hindu and Buddhist Initiations in India and Nepal, edited by Astrid Zotter and Christof Zotter, Harrassowitz Verlag, 2010, 167-181.

Gutschow, Niels and Axel Michaels. Growing Up: Hindu and Buddhist Initiation Rituals among Newar Children in Bhaktapur, Nepal. Harrassowitz Verlag, 2008.

Gutschow, Niels and Axel Michaels. Getting Married: Hindu and Buddhist Marriage Rituals among the Newars of Bhaktapur and Patan, Nepal. Harrassowitz Verlag, 2012.

Gyanwali, Pradip. “Janmadekhi Mrityusammaka Sanskarko Sandarbhama Samajik Sudhar RaSanskritik Rupantaranko Prashna.” Samskar (Rituals), compiled by Khagendra Sangraula, Vivek Srijanshil Prakashan, 2014, 146-156.

Kaundinnyayan, Aamodhvardhan. “Antestikriyako Vaidik Swarup.” Kantipur Daily Vol. 05 No. 08 (2071), 6.

Michaels, Axel and Christoph Wulf. "Rethinking the Body: An Introduction.” The Body in India: Ritual, Transgression, Performativity, Akademic Verlag, 2009, 9-24.

Michaels, Axel. "Perfection and Mishaps in Vedic Rituals.” When Rituals Go Wrong: Mistakes, Failure, and the Dynamics of Ritual, edited by Ute Husken, Brill, 2007, 121- 132.

Michaels, Axel. "Newar Hybrid Ritual and its Language in Hindu Initiations.” Hindu and Buddhist Initiations in India and Nepal, edited by Astrid Zotter and Christof Zotter, Harrassowitz Verlag, 2010, 137- 150.

Paudyal, Ghanashya Sharma. "Hindu Ra Hindu Samskarharu.” Samskar (Rituals), compilted by Khagendra Sangraula, Vivek Srijanshil Prakashan, 2014, 62- 
The Death Rite in New Republic Nepal: Should It Be Shortened? 104

117.

Pollock, Sheldon. The Language of the Gods in the World of Men. University of California Press, 2004.

Prashreet, Modanath ."Manisako Mrityupachhi Garnuparne Kaj-Kriya, Shraddha Aadi Vishayako Sambandhama.” Samskar (Rituals), compiled by Khagendra Sangraula, Vivek Srijanshil Prakashan, 2014.

Rappaport, Roy A. Ritual and Religion in the Making of Humanity. CUP, 1999.

Rospatt, Alexander von. "The Consecration Ceremony in the Kriyasamgraha and Newar Buddhism.” Hindu and Buddhist Initiations in India and Nepal, edited by Astrid Zotter and Christof Zotter, Harrassowitz Verlag, 2010, 197-260.

Sangraula, Khagendra. "Samskar Sudharka Kura.” Samskar (Rituals), compiled by Khagendra Sangraula, Vivek Srijanshil Prakashan, 2014, 52-61.

Schieffelin, Edward L. "Introduction.” When Rituals Go Wrong: Mistakes, Failure, and the Dynamics of Ritual, edited by Ute Husken, Brill, 2007, 1-20.

Singh, Mohanvikram. "Jibansita Jodiyeka Samskar, Aacharanra Chadbadharuko Saidhantik Vivechana.” Samskar (Rituals), compiled by Khagendra Sangraula, Vivek Srijanshil Prakashan, 2014, 22-37.

Srinivas, M.N. Village, Caste, Gender and Method. OUP, 1998.

Subedi, Abhi. Nepali Theatre as I See It. Aarohan Theatre Group, 2006.

Stietencron, Heinrich von. Hindu Myth, Hindu History. Permanent Black, 2005.

Thapar, Romila. Cultural Pastes. OUP, 2004.

“Chhoriharuko Kaandhama Dr. Devakotako Parthiv Sharir.” Kantipur Daily, 10 Nov. 2014, p.01.

Turner, Victor. "Are there universals of performance in myth, ritual, and drama.” By Means of Performance, edited by Richard Schechner and Willa Appel. CUP, 1990, 8-18.

Zotter, Christof. "Notes on the Evolution of an Imitation Ritual: The Vratabandha of the Bahun and Chetri." Hindu and Buddhist Initiations in India and Nepal, edited by Astrid Zotter and Christof Zotter, Harrassowitz Verlag, 2010. 